\title{
Esophagus and Esophagogastric Junction Cancer Pathologic Primary Tumor TNM Finding v8
}

National Cancer Institute

\section{Source}

National Cancer Institute. Esophagus and Esophagogastric Junction Cancer Pathologic

Primary Tumor TNM Finding v8. NCI Thesaurus. Code C133373.

A pathologic finding about one or more characteristics of esophagus and esophagogastric junction cancer, following the rules of the TNM AJCC V8 classification system as they pertain to staging of the primary tumor. 